I Innlegg på inntil $\mathbf{4 0 0}$ ord lastes opp i http://mc.manuscriptcentral.com/tidsskriftet.

Redaksjonen forbeholder seg retten til å foreta redaksjonelle endringer.

Forfattere av vitenskapelige artikler har tilsvarsrett (jf. Vancouver-gruppens regler).

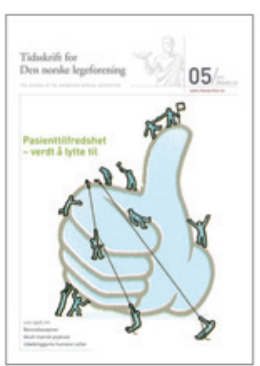

\section{Vikarierende motiver om rituell omskjæring og helsehjelp}

Lege Rolf Kirschner kommer i Tidsskriftet nr. 5/2012 med noen underlige utfall mot undertegnede (1). (Bakgrunnen er en kritisk kommentar om rituell omskjæring som jeg skrev sammen med Reidar Pedersen og Anne Hambro Alnæs (2)). For det første mener han at det er den lutherske teologen i meg som har tatt frem slåsshansken. Da overser han helt at mine to medforfattere, som er henholdsvis lege og filosof (Reidar Pedersen) og medisinsk antropolog (Anne Hambro Alnæs) også har bidratt til kommentaren. For det tredje glemmer han i farten å nevne at jeg ikke er praktiserende prest, verken i eller utenfor Den norske kirke, og at jeg dessuten har to andre akademiske bein å stå på (medisin og filosofi). Det er ikke spor av teologiske argumenter i kommentaren. For det fjerde unnlater han å nevne at mange prester i Den norske kirke faktisk støtter Kirschner i at rituell omskjæring bør kunne tilbys ved offentlige sykehus i Norge, og det nettopp av respekt for at dette er en religiøs praksis med lange tradisjoner innen islam og jødedom. Selv er jeg ikke praktiserende kristen, noe jeg for øvrig aldri har forsøkt å legge skjul på. I vår kommentar til denne praksis drøfter også vi respektsiden av dette problemet, med henvisning til UNESCOs verdenserklæring om bioetikk og menneskerettigheter. Og vi er enig i UNESCO-erklæringens påpeking av at respekt for kulturell forskjellighet har en grense, nemlig når denne respekten har som konsekvens at grunnleggende menneskerettigheter krenkes. Som vi har gjort rede for i kommentaren, mener vi derfor at det å påføre et spedbarn et mutilerende inngrep av irreversibel karakter, ikke er i samsvar med grunnleggende menneskerettigheter.

Til sist tre ting: Det medfører riktighet at en forlenget versjon av vår kommentar ble sendt som høringssvar fra Senter for medisinsk etikk, Universitetet i Oslo, til Helseog omsorgsdepartementet, og at vi etter forespørsel fra Tidsskriftets redaktør utarbeidet en kommentarartikkel til Tidsskriftet om dette spørsmålet. I begge disse tekstene tok vi oss altså den frihet å påpeke at departementet i sitt høringsdokument hadde innskrenket høringsinstansenes valgmuligheter på utilbørlig vis, ettersom muligheten til å si nei til rituell omskjæring ved offentlige sykehus ikke inngikk blant de handlingsalternativer som skulle vurderes.

\section{Jan Helge Solbakk}

j.h.solbakk@medisin.uio.no

Jan Helge Solbakk (f. 1956) er cand.med., cand.theol., dr.philos. og professor i medisinsk etikk ved Senter for medisinsk etikk, Institutt for helse og samfunn, Det medisinske fakultet, Universitetet i Oslo.

Ingen oppgitte interessekonflikter.

\section{Litteratur}

1. Kirschner R. Om rituell omskjæring og helsehjelp. Tidsskr Nor Legeforen 2012; 132: 508.

2. Solbakk JH, Pedersen R, Alnæs AH. Rituell omskjæring er ikke helsehjelp. Tidsskr Nor Legeforen 2012; 132: 134-5.

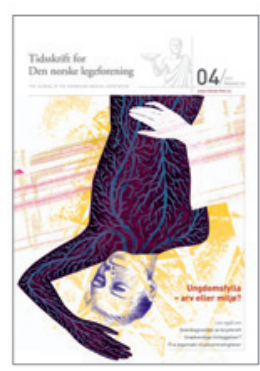

\section{Autisme - mer miljø enn gener!}

I Tidsskriftet nr. 4/2012 skriver Ragnhild Ørstavik (1) om en ny tvillingstudie fra Stanford University, som viste at miljøet hadde en større betydning enn gener (2). Camilla Stoltenberg ved Nasjonalt Folkehelseinstitut er ifølge innlegget ikke enig med de amerikanske forskerne (1).

Jeg synes derimot at studien høres plausibel ut. Allerede foreliggende studier viser at autister har skyhøye kvikksølvverdier målt $\mathrm{i}$ håret, en nedsatt evne til å skylle ut tungmetaller, og ofte positiv effekt av en kvikksølvutledende behandling $(3,4)$. Adams og medarbeidere (5) og Vojdani og medarbeidere (6) har undersøkt kvikksølvbelastningen hos autistiske barn og postu- lerer at det store forbruket av antibiotika hos disse barna er medansvarlig for de kjente mage-tarmproblemene, slik som intoleranse for melkekasein og gluten og blokkeringen for kvikksølvutrenskningen.

Heiko Santelmann heiko@online.no

Heiko Santelmann (f. 1950) er allmennpraktiserende lege, med spesialkompetanse i sammensatte lidelser. Han har forskererfaring fra Institutt for allmennmedisin, Universitetet i Oslo. Ingen oppgitte interessekonflikter.

Litteratur

1. Ørstavik R. Autisme - arv eller miljø? Tidsskr Nor Legeforen 2012; 132: 408

2. Hallmayer J, Cleveland S, Torres A et al. Genetic heritability and shared environmental factors among twin pairs with autism. Arch Gen Psychiatry 2011; 68: 1095-102.

3. Mutter J, Naumann J, Schneider R et al. Mercury and autism: accelerating evidence? Neuro Endocrinol Lett 2005; 26: 439-46.

4. Reichelt K-L. Autistiske syndromers biokjemi og psykosofysiologi. Tidsskr Nor Lægeforen 1994; 114: $1432-4$

5. Adams JB, Romdalvik J, Ramanujam VM et al. Mercury, lead, and zinc in baby teeth of children with autism versus controls. J Toxicol Environ Health A 2007; 70: 1046-51

6. Vojdani A, Pangborn JB, Vojdani E et al. Infections, toxic chemicals and dietary peptides binding to lymphocyte receptors and tissue enzymes are major instigators of autoimmunity in autism. Int J Immunopathol Pharmacol 2003; 16: 189-99.

\section{Vaksinasjon mot pandemisk influensa 2009}

Charlotte Haug hevder i Tidsskriftet nr. 5/2012 at Folkehelseinstituttet 23.10. 2009 visste at vaksinen Pandemrix ikke var «klinisk testet», at «WHOs egen vaksinesikkerhetskomité hadde uttrykt bekymring» og at den nye influensaen var «ufarlig for de aller fleste» (1). Det er én feil, en delvis feil og én rett påstand.

Vaksinen var klinisk testet. For det første var Pandemrix med et annet virus (fugleinfluensaviruset $\mathrm{H} 5 \mathrm{~N} 1$ ) testet på flere tusen personer. For det andre hadde flere tusen personer fått Pandemrix med A(H1N1)pdm09-viruset i kliniske studier, hvorav noen er omtalt i det europeiske legemiddelverkets vurderingsrapport 24.9. 2009 (2). For det tredje begynte flere land med gode systemer for bivirkningsovervåking å ta i bruk Pandemrix i midten av oktober. 